\title{
Stormwater Quality Characteristics in (Dutch) Urban Areas and Performance of Settlement Basins
}

\section{Floris C. Boogaard ${ }^{1,2,3 *}$, Frans van de Ven ${ }^{1,4}$, Jeroen G. Langeveld ${ }^{1,5}$ and Nick van de Giesen ${ }^{1}$}

1 Department of Water Management, Faculty of Civil Engineering and Geosciences, Delft University of Technology, P.O. Box 5048, 2600 GA Delft, The Netherlands;

E-Mails: F.H.M.vandeVen@tudelft.nl (F.V.); jeroen.langeveld@rhdhv.com (J.G.L.);

n.c.vandegiesen@tudelft.nlc (N.G.)

2 TAUW, Zekeringstraat 43g, P.O. Box 20748, 1001 NS Amsterdam, The Netherlands

3 Hanze University of Applied Sciences, Zernikeplein 7, P.O. Box 30030, 9700 RM Groningen, The Netherlands

4 Deltares, Princetonlaan 6-8, P.O. Box 85467, 3508 AL Utrecht, The Netherlands

5 Royal HaskoningDHV, Barbarossastraat 35, P.O. Box 151, 6500 AD Nijmegen, The Netherlands

* Author to whom correspondence should be addressed; E-Mail: f.c.boogaard@ tudelft.nl;

Tel.: +31-6515-56-82-6; Fax: +31-2068-48-92-1.

Received: 31 August 2013; in revised form: 5 March 2014 / Accepted: 6 March 2014 /

Published: 19 March 2014

\begin{abstract}
Stormwaters, flowing into storm sewers, are known to significantly increase the annual pollutant loads entering urban receiving waters and this results in significant degradation of the receiving water quality. Knowledge of the characteristics of stormwater pollution enables urban planners to incorporate the most appropriate stormwater management strategies to mitigate the effects of stormwater pollution on downstream receiving waters. This requires detailed information on stormwater quality, such as pollutant types, sediment particle size distributions, and how soluble pollutants and heavy metals attach themselves to sediment particles. This study monitored stormwater pollution levels at over 150 locations throughout the Netherlands. The monitoring has been ongoing for nearly 15 years and a total of 7,652 individual events have been monitored to date. This makes the database the largest stormwater quality database in Europe. The study compared the results to those presented in contemporary international stormwater quality research literature. The study found that the pollution levels at many of the Dutch test sites did not meet the requirements of the European Water Framework Directive (WFD) and
\end{abstract}


Dutch Water Quality Standards. Results of the study are presented and recommendations are made on how to improve water quality with the implementation of Sustainable Urban Drainage Systems (SUDS) devices.

Keywords: stormwater quality; stormwater characteristics; monitoring; stormwater treatment

\section{Introduction}

Storm sewers are known to contribute significantly to annual pollutant loads to the receiving waters and to cause degradation of urban receiving waters [1]. The European Water Framework Directive (WFD) demands enhanced protection of the aquatic environment. As a consequence, the WFD requires municipalities to address the emissions from drainage systems adequately and to take action when these emissions affect the quality of receiving waters.

Sustainable urban drainage systems, based on settling, are often implemented in urban areas. such as sedimentation basins (Figure 1a).lamellar settlers (Figure 1b).or ponds. The implementation of these Sustainable Urban Dranage Systems (SUDS) is widely accepted in the Netherlands and other countries without a prior check on the obtainable removal efficiencies. For a good indication of the removal efficiency of these systems knowledge of the quality and characteristics of stormwater is essential.

Figure 1. (a) Sediment basin in Amsterdam (sludge from stormwater system during maintenance after eight years) and (b) lamellar settler in Gouda.

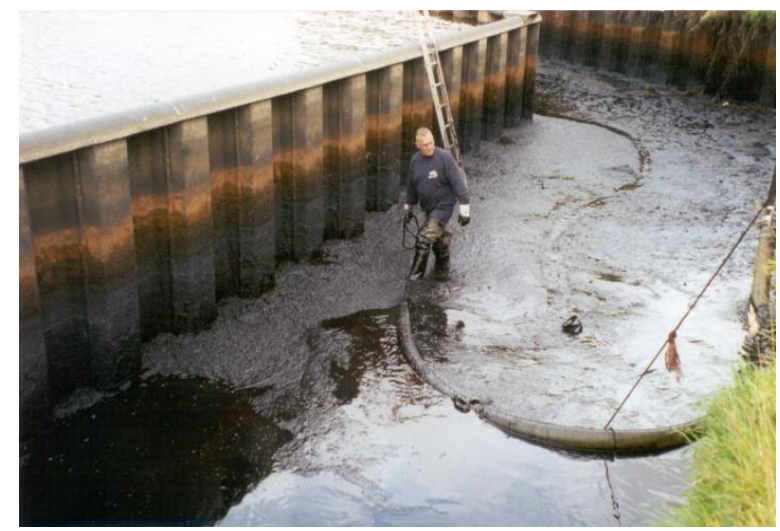

(a)

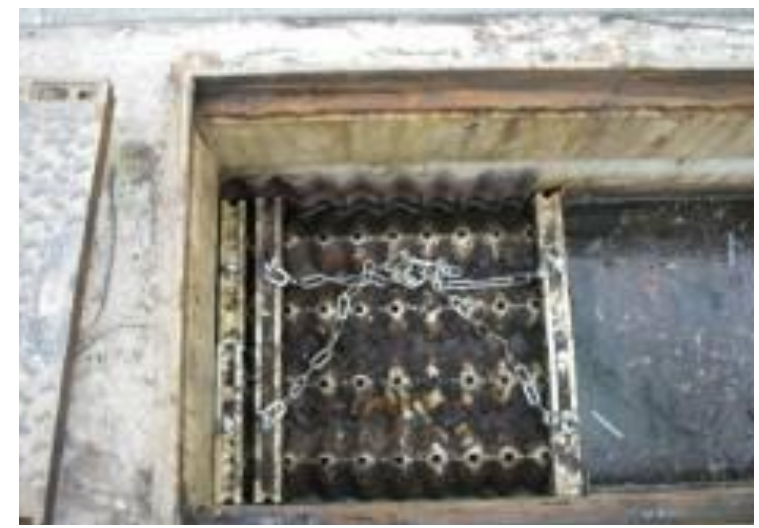

(b)

The efficiency of these SUDS highly depends on the dimensions of the facility and on its implementation in the field [2]. For the determination of the removal efficiency of SUDS information about stormwater quality and characteristics is essential. Acquiring the following information is strongly advised:

- stormwater quality levels (which determines the need for stormwater treatment techniques based on the removal of solids);

- behavior of pollutants (which pollutants are bound to which particles sizes and which are dissolved) 
- particle size distribution (gives an indication on what particles are likely to be removed by sedimentation)

This paper discusses the use of treatment techniques based on stormwater characteristics, which are derived from the Dutch national stormwater quality database, combined with international literature data.

\section{Materials and Methods}

The monitoring data in the Dutch database were collected over a fifteen-year period. (the earliest measurement in the database is from 1999) from more than 60 municipalities and over 150 locations throughout the country. The total number of individual events included in the database now is 7,652 . The national database of all collected stormwater monitoring data provides a scientific analysis of the data, and provide information and recommendations for improving the quality monitoring. Each data set has gone through a quality assurance/quality control review based on reasonableness of data, extreme values, relationships among parameters, sampling methods and a review of the analytical methods [3].

Most data on the characterization of stormwater quality of contaminants (particle size distribution, bound to suspended solids. etc.) was found by sampling stormwater during stormwater events. Most of the samples were grab samples and were analyzed in certified laboratories according to standard methods and standard quality control/assurance procedures (see Table 1).

Table 1. Water quality parameters analysed.

\begin{tabular}{lll}
\hline Water Quality Problem Related & Parameter & Reference Method \\
\hline General parameter & TSS & NEN-EN 872 \\
\hline \multirow{2}{*}{ Oxygen depletion } & Biochemical Oxygen Demand (BOD) & NEN-EN 1899 1\&2 \\
\cline { 2 - 3 } & Chemical Oxygen Demand (COD) N & EN 6633:2006 \\
\hline \multirow{2}{*}{ Eutrophication } & Total Kjeldahl Nitrogen (TKN) & NEN-ISO 5663:1993 \\
\hline & Total Phosphorus (TP) & NEN 6663 \\
Toxicity & Lead $(\mathrm{Pb})$ & NEN-EN-ISO 17294-2:2004 \\
& Zinc $(\mathrm{Zn})$ & \\
\hline Microbiological quality & Copper $(\mathrm{Cu})$ & \\
\hline Particle size analysis & E. coli & NEN 6571:1982 \\
\hline
\end{tabular}

Only data from well-described stormwater research have been used for the database. In addition. the following information was entered: aim of the research, site descriptions (state, municipality, land use components), and sampling information (date, season, sampling method, sample type) with links to the original research reports and articles. The database has its focus on urban areas, divided into residential areas (roofs and roads) and commercial areas; industrial areas were not represented. Different water quality parameters were characterized through the calculation of minimum, maximum, mean, median, and 90th percentile values.

Distribution between dissolved and particle-bound pollution loads were determined by comparing the total concentration in samples with the filtered sample $(0.45 \mu \mathrm{m})$. 
Particle size distribution was determined by a particle counter (HRLD-400HC). The particle counter measured the absolute amount of particles for every particle size (quantified intervals of $0.77 \mu \mathrm{m}$ ) between 0 and $1,000 \mu \mathrm{m}$.

\section{Results}

\subsection{Stormwater Quality}

The recorded concentrations of the pollutants from the database have been compared to Dutch quality standards maximum acceptable concentration (MAC) for receiving waters [4]. These contaminant concentration levels are summarized in Table 2.

The stormwater quality measurements exceeded the MAC for nutrients (TKN and TP) and for copper and zinc. In addition, the microbiological parameters showed that stormwater by far exceeds the standards of 200 E. coli/100 $\mathrm{mL}$ for swimming water [5].

Table 2. Concentrations of pollutants in stormwater runoff from Dutch residential areas roofs and roads.

\begin{tabular}{|c|c|c|c|c|c|c|c|c|c|}
\hline & $\begin{array}{r}\text { Cd } \\
\mu g / L \\
\end{array}$ & $\begin{array}{r}\mathbf{C r} \\
\mu \mathrm{g} / \mathrm{L} \\
\end{array}$ & $\begin{array}{r}\mathbf{C u} \\
\mu \mathrm{g} / \mathrm{L} \\
\end{array}$ & $\begin{array}{r}\text { Hg } \\
\mu \mathrm{g} / \mathrm{L} \\
\end{array}$ & $\begin{array}{r}\mathbf{P b} \\
\mu \mathrm{g} / \mathrm{L} \\
\end{array}$ & $\begin{array}{r}\mathbf{N i} \\
\mu \mathrm{g} / \mathrm{L} \\
\end{array}$ & $\begin{array}{r}\mathbf{Z n} \\
\mu \mathrm{g} / \mathrm{L} \\
\end{array}$ & $\begin{array}{c}\text { PAH10 } \\
\mu \mathrm{g} / \mathrm{L} \\
\end{array}$ & $\begin{array}{c}\text { PAH16 } \\
\mu \mathrm{g} / \mathrm{L} \\
\end{array}$ \\
\hline Mean Dutch & 0.27 & 6.2 & 19 & 0.05 & 18 & 5.6 & 102 & 0.8 & 60.9 \\
\hline median & 0.15 & 1.1 & 11 & 0.06 & 6 & 3.6 & 60 & 0.8 & 1.5 \\
\hline 90 percentile & 0.50 & 12.0 & 35 & 0.08 & 43 & 10.0 & 250 & 1.1 & 1.5 \\
\hline $\mathrm{n}$ measurements & 152 & 141 & 686 & 118 & 682 & 155 & 684 & 145 & 106 \\
\hline MAC solved & 0.4 & 8.7 & 1.5 & 0.20 & 11.0 & 5.1 & 9.4 & 2.3 & \\
\hline MAC total & 2.0 & 84 & 3.8 & 1.2 & 220 & 6.3 & 40 & 4.3 & \\
\hline \multirow[t]{2}{*}{ required $\mathrm{R}$} & $0.0 \%$ & $0.0 \%$ & $80.5 \%$ & $0.0 \%$ & $0.0 \%$ & $0.0 \%$ & $60.7 \%$ & $0.0 \%$ & \\
\hline & $\begin{array}{c}\text { oil } \\
\mathrm{mg} / \mathrm{L} \\
\end{array}$ & $\begin{array}{c}\mathbf{C l} \\
\mathrm{mg} / \mathrm{L} \\
\end{array}$ & $\begin{array}{c}\mathbf{F e} \\
\mathrm{mg} / \mathrm{L}\end{array}$ & $\begin{array}{l}\text { BOD } \\
\mathrm{mg} / \mathrm{L}\end{array}$ & $\begin{array}{l}\text { COD } \\
\mathrm{mg} / \mathrm{L}\end{array}$ & $\begin{array}{l}\text { Ptot } \\
\mathrm{mg} / \mathrm{L}\end{array}$ & $\begin{array}{l}\mathbf{N}-\mathbf{k j} \\
\mathrm{mg} / \mathrm{L}\end{array}$ & $\begin{array}{c}\text { SS } \\
\mathrm{mg} / \mathrm{L} \\
\end{array}$ & $\begin{array}{c}\text { E. coli } \\
\text { kve/100 mL }\end{array}$ \\
\hline Mean Dutch & 37 & 18.3 & 1.8 & 5.7 & 32 & 0.4 & 1.9 & 29.9 & $1.9 \mathrm{E}+04$ \\
\hline median & 1 & 11.0 & 1.1 & 3.1 & 20.0 & 0.3 & 1.1 & 11 & $6.7 \mathrm{E}+03$ \\
\hline 90 percentile & 90.8 & 33 & 2.9 & 12.5 & 60 & 1.0 & 3.1 & 50 & $3.5 \mathrm{E}+04$ \\
\hline n measurements & 149 & 321 & 60 & 219 & 681 & 107 & 590 & 1,262 & 116 \\
\hline MAC dissolved & & & & & & 0.15 & $2.2(\mathrm{~N}$-tot $)$ & & $1.0 \mathrm{E}+03$ (swimming water) \\
\hline required $\mathrm{R}$ & & & & & & $64.5 \%$ & $0.0 \%$ & & $94.8 \%$ \\
\hline
\end{tabular}

Notes: Green concentrations are under total MAC value, orange is exceeding MAC value and red is exceeding the MAC by 2 times or more.

Table 2 shows the required removal efficiency ("required R") to achieve the quality standard. To achieve the MAC for copper and zinc, the stormwater treatment facilities must have a removal efficiency of $80.5 \%$ and $60.7 \%$.respectively. For phosphate the removal efficiency needs to be in the order of $65 \%$. 
The quality and characteristics of stormwater can strongly differ per country, location and even between and during stormwater events [6]. A comparison with international data from USA, Australia, and Europe is given in Table 3.

Table 3. Dutch and international stormwater quality data from residential areas in USA, Australia, and Europe.

\begin{tabular}{llcccc}
\hline Substance & Unit & Dutch [3] $^{\mathbf{a}}$ & USA NSQD [7] & $\begin{array}{c}\text { Europe/Germany } \\
\text { ATV Database [8] }\end{array}$ & Worldwide [9] $^{\mathbf{c}}$ \\
\hline TSS & mg/L & 17 & Median & Mean & Mean \\
BOD & mg/L & 5.7 & 48 & 141 & 150 \\
COD & mg/L & 32 & 9 & 13 & \\
TKN & mg N/L & 1.9 & 55 & 81 & 2.1 \\
TP & mg P/L & 0.4 & 1.4 & 2.4 & 0.35 \\
PB & ug/L & 18 & 0.3 & 0.42 & 140 \\
Zn & ug/L & 102 & 12 & 118 & 250 \\
CU & ug/L & 19 & 73 & 275 & 50 \\
\hline
\end{tabular}

Notes: ${ }^{\text {a }}$ Dutch STOWA database (Version 3.1.2013) based on data monitoring projects in the Netherlands, residential and commercial areas, with n ranging from 26 (SS) to 684 (Zn); ${ }^{\text {b }}$ NSQD monitoring data collected over nearly a ten-year period from more than 200 municipalities throughout the USA. The total number of individual events included in the database is 3.770 with most in the residential category (1.069 events); ${ }^{\mathbf{c}}$ ATV database [10] partly based on the US EPA nation wide runoff programme (NURP), with $\mathrm{n}$ ranging from 17 (TKN) to 178 (SS); ${ }^{\mathbf{d}}$ Typical pollutant concentrations based on review of worldwide [10] and Melbourne [11] data.

The data from the Dutch database shows that the stormwater monitored in the Netherlands is relatively low in suspended solids. BOD and COD and heavy metals show low concentrations compared to international data, whereas the nutrient concentrations are within the international range.

\subsection{Fraction of Pollutants Attached to Particles}

Treatability of stormwater runoff by sedimentation depends on the degree to which pollutants are bound to particles. Therefore, the distribution between dissolved and particle-bound pollution loads has been determined. Up to 90 measurements were taken from stormwater sewers at 25 different locations in the Netherlands. Distribution between dissolved and particle-bound pollution load was determined by comparing the total concentration in samples with the filtered sample $(0.45 \mu \mathrm{m})$.

Figure 2 shows the average values of pollutants bound to suspended solids in stormwater from roofs and roads in residential areas (yellow bars on chart). The plus and minus gives the range of the data values which indicates a large variability in the ability of pollutants to bind to suspended solids. The red dot gives the typical average value found throughout the world, which was taken from comparable international studies [12]. 
Figure 2. Distribution of pollutants in (Dutch) stormwater (90 samples from 25 locations).

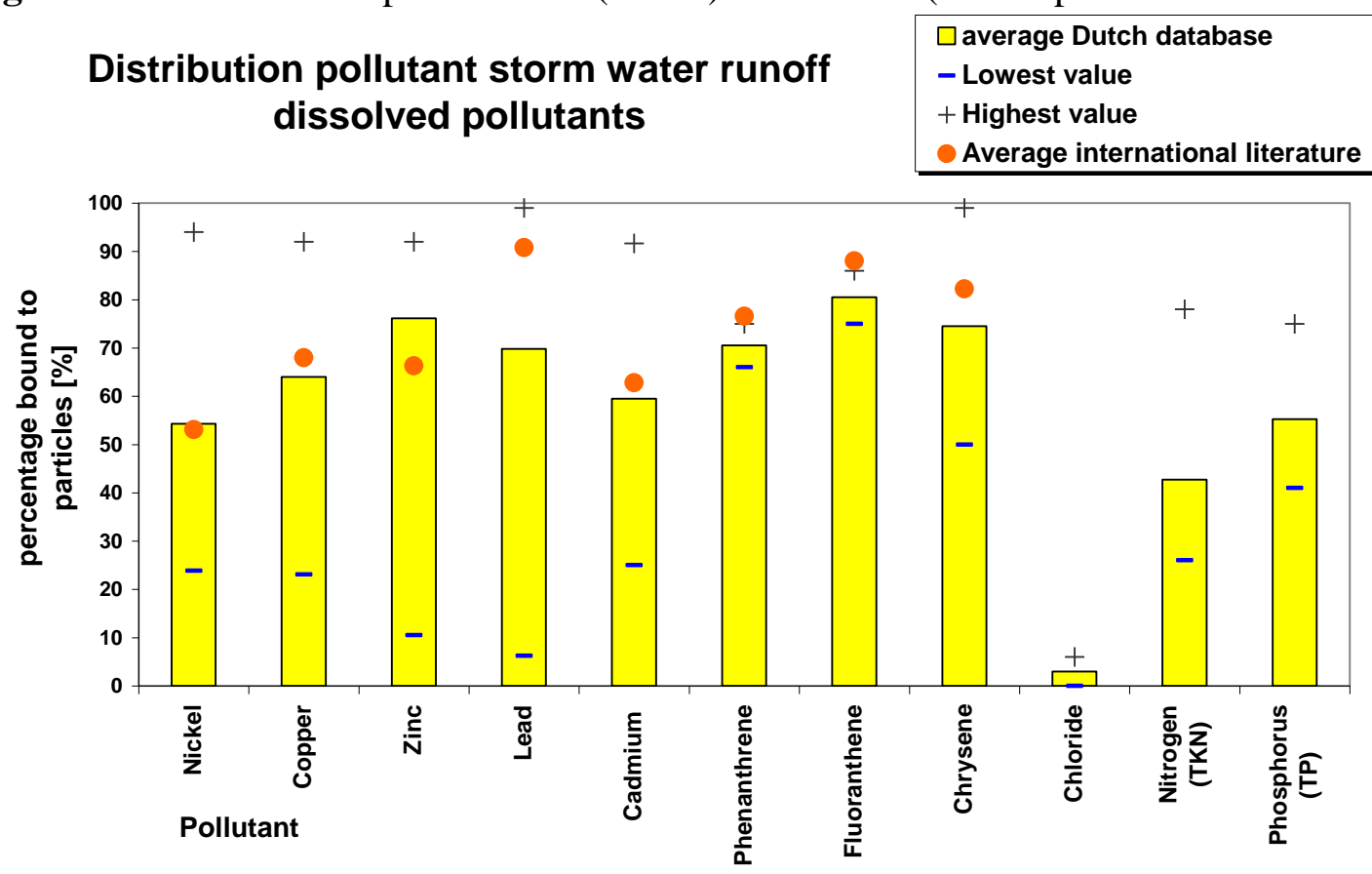

From Figure 2, the pollutant behavior can be derived. Nutrients are less bound to particles than heavy metals and PAHs and therefore harder to retain than other contaminants. Within a certain pollutant group, such as metals, the individual pollutants have their own specific behavior.

The average Dutch research results are similar to the average from international data [13,14]. By using settlement facilities Figure 2 will give an indication of the maximum removal efficiency rate that can be achieved. To get a detailed insight of the removal efficiency, knowledge of particle size distribution of suspended sediment in stormwater is needed to find out which particles can be captured by settlement facilities.

As heavy metals are bound in the order of $65 \%$ (lead up to $90 \%$ ) a higher removal rate with settlement basins should not be expected and is rarely determined in the field (see Table 4). If $80 \%$ removal rate is needed to achieve MAC for copper, which is bound on average at $65 \%$ to suspended solids, then it is it is unlikely that this quality standard will be achieved with sedimentation basins.

\subsection{Particle Size Distribution}

To get detailed information on the achievements of sustainable urban drainage systems an examination of particle size distribution is needed. Measurements at 25 locations were taken in stormwater sewers and the particle size distribution was determined. The results are given in Figure 3.

The particle size distribution varies with each different stormwater sewer location. Half of the mass consists of particles smaller than $90 \mu \mathrm{m}$. Compared to other international research it seems that Dutch stormwater is within the range of international data [12] (Figure 4). 
Table 4. Comparing required removal efficiency and basic pollutant behaviour.

\begin{tabular}{|c|c|c|c|c|c|c|}
\hline & $\begin{array}{l}\text { Removal } \\
\text { Efficiency } \\
\text { Required }\end{array}$ & $\begin{array}{l}\text { Bound to } \\
\text { Particles }\end{array}$ & $\begin{array}{l}\text { Removal Efficiency } \\
\text { Compact Lamellar } \\
\text { Settlement Basin } \\
\text { Netherlands a }(\%) \\
\end{array}$ & $\begin{array}{l}\text { International } \\
\text { Removal Efficiency } \\
\text { Compact Settlement } \\
\text { Basin }(\%)^{\text {b }}\end{array}$ & Pond 1,c & $\begin{array}{l}\text { International } \\
\text { Removal Efficiency } \\
\text { Settlement Basins } \\
\text { (Wet Ponds) }^{d}\end{array}$ \\
\hline copper & $80 \%$ & $65 \%$ & 21 & $29-40$ & & 26 \\
\hline zinc & $60 \%$ & $55 \%$ & 23 & $-38 \pm 27$ & 32 & 26 \\
\hline nitrogen & $65 \%$ & $40 \%$ & 15 & & $21(\mathrm{Nkj})$ & 4 \\
\hline TSS & & & & & 62 & 47 \\
\hline
\end{tabular}

Notes: ${ }^{\mathbf{a}}$ Lamellar settlement basin [5]; ${ }^{\mathbf{b}}$ compact settlement basin [15]; ${ }^{\mathbf{c}}$ vegetated pond [16]; ${ }^{\mathbf{d}}$ National pollutant removal performance database (2nd edition); ${ }^{1}$ Drainage area 177 hectares, pond area 1.3 hectares, mean depth $1.2 \mathrm{~m}$, storage volume $8.4 \mathrm{~mm}$.

Figure 3. Particle size distributions in several Dutch stormwater sewer systems.

\section{Particle size distribution in stormwater sewers Netherlands}

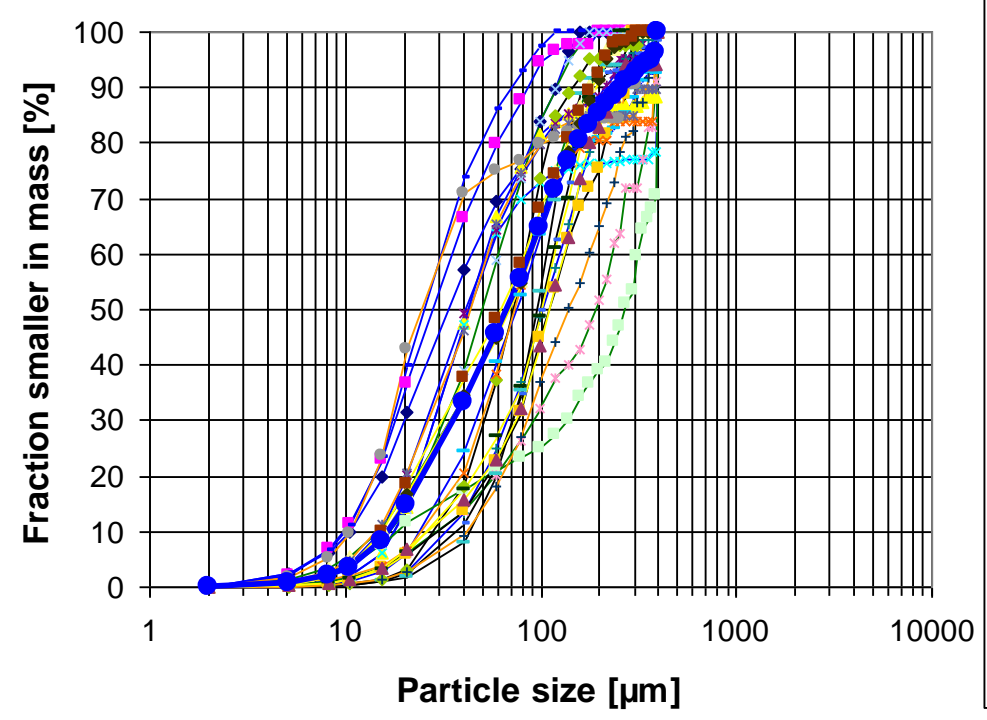

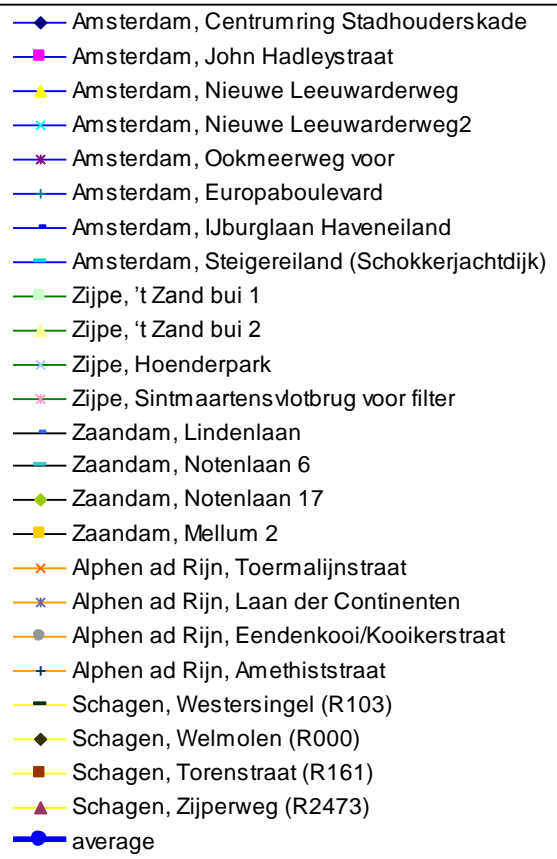

\subsection{Stormwater Characteristics and Conclusions on Removal Efficiency}

The stormwater quality data showed that to achieve the MAC for copper and zinc the stormwater treatment facilities must have a removal efficiency of $80.5 \%$ and $60.7 \%$.for nutrients in the order of $65 \%$. The characterization of stormwater quality of these contaminants (particle size distribution, bound to suspended solids, etc.) showed that it is not likely to achieve this. Achieved removal efficiencies in the field are shown in Table 4.

In the overview of the "BMPs orders of preference for the removal of identified pollutants" [17] settlement tanks were ranked the lowest for removal of heavy metals. 
Figure 4. Particle size distributions in several stormwater sewer systems around the world.

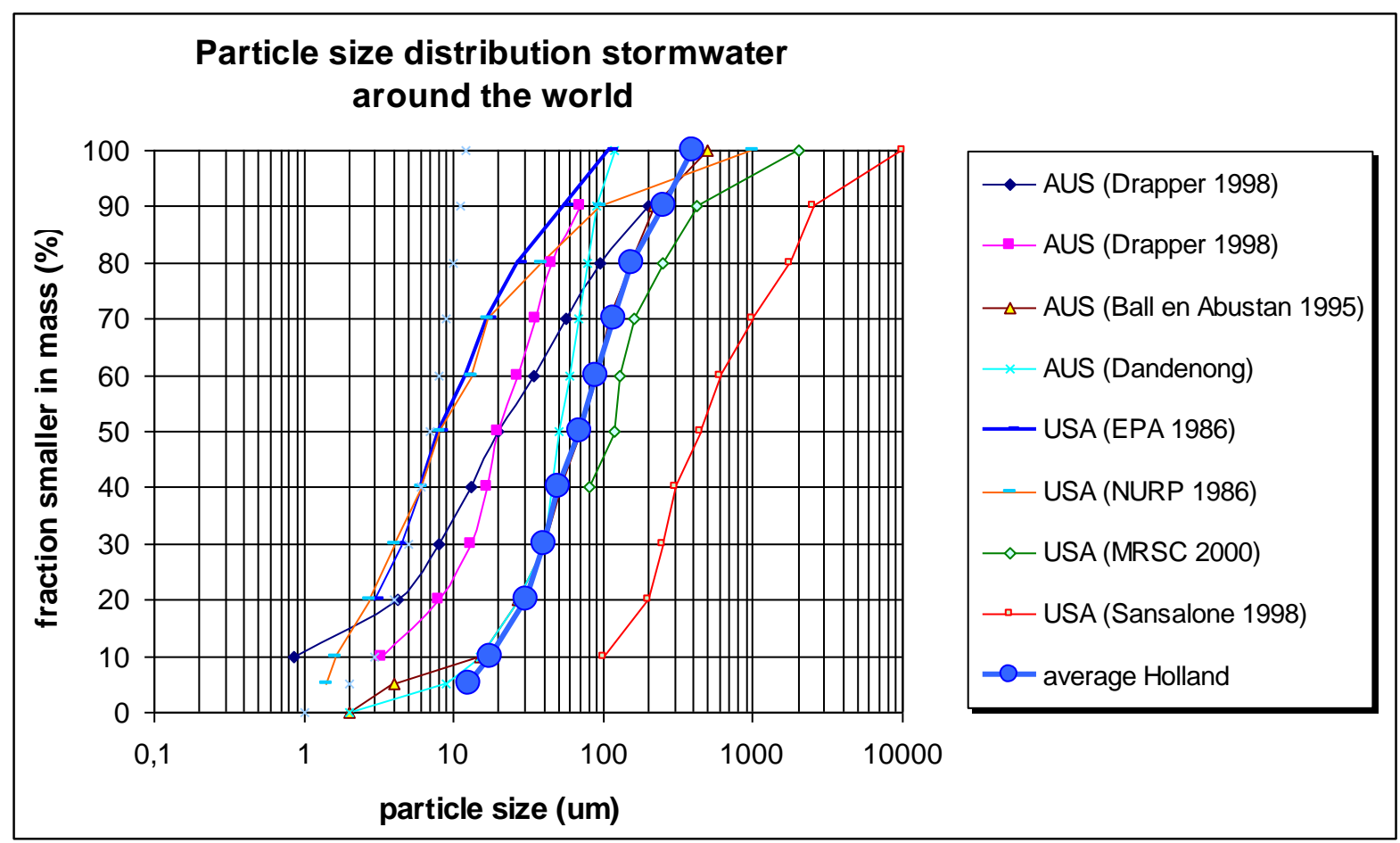

\section{Discussion}

Detailed data on the amount or percentage of contaminants bound to a specific particle size fraction and under different conditions are rare. Most contaminants are bound to smaller fractions of particles $[18,19]$.

From the research it can be concluded the distribution can differs substantially per location, which is expected since the particle size distribution and (un)bound fractions show a large variation too. Most of the research focussed on heavy metals. In characterization of solid and metal element distributions in urban highway stormwater more than $50 \%$ of copper, zinc, and lead are bound to particles smaller than $75 \mu \mathrm{m}$ [20]. Since the removal efficiency of suspended solids is in the order of $>60 \%$ for zinc in order to achieve the MAC quality standard, a high amount of particles $<70 \mu \mathrm{m}$ need to be removed.

\section{Conclusions}

From the acquired data on stormwater quality and characteristics it is concluded that to achieve the WFD and Dutch quality standards for copper and zinc the stormwater treatment facilities must have removal efficiency of $80 \%$ and $60 \%$ respectively, and for nutrients in the order of $65 \%$.

These removal efficiencies are unlikely to be achieved by settlement basins if we study the distribution between dissolved and particle-bound pollution loads of these pollutants. As heavy metals are bound in the order of $65 \%$ (lead up to $90 \%$ ) a higher removal rate with settlement basins should not be expected and is rarely observed in the field. If $80 \%$ removal rate is needed to achieve MAC for copper, which is bound on average at $65 \%$ to suspended solids, then it is it is unlikely that this quality standard will be achieved with sedimentation basins. 
Comparing Dutch stormwater characteristics to international data the average percentage of pollutants bound to suspended solids are comparable. Data on particle size distribution are less coherent. The particle size distribution demonstrated that about $50 \%$ of the mass of stormwater measurements (average of 25 locations) consists of particles smaller than $90 \mathrm{um}$. As the fine fraction is responsible for most of the pollution load, it is important to know whether SUDS are capable of removing the finer solids. With the insight of particle distribution further research can focus on the ability of different products of capturing these fine particles.

To conclude: regarding the characteristics of stormwater quality and required removal efficiency for achieving MAC demands SUDS based on settling as the primarily treatment process, will not be able to achieve the required removal efficiencies. An additional stormwater treatment step with filtration or adsorption will be necessary in order to comply with the MAC and or WFD.

\section{Acknowledgements}

The authors would like to gratefully acknowledge the funding by the EU Interreg project IVb SKINT (Skills integration and new Technologies) and the additional funding by STOWA Tauw BV and TU Delft.

\section{Author Contributions}

Floris Boogaard: performed this work as part of his $\mathrm{PhD}$ at Technical University in Delft, senior consultant at consulting agency Tauw and his professorship at Hanze University of Applied Sciences. Floris Boogaard is the primary author of this publication and performed the field and office work with the assistance of (student) workers. Jeroen Langeveld, Frans van de Ven and Nick van de Giesen provided methodological support on the study and editorial assistance on the publication.

\section{Conflicts of Interest}

The authors declare no conflicts of interest.

\section{References}

1. House, M.A.; Ellis, J.B.; Herricks, E.E.; Hvitved-Jacobsen, S.J.; Lijklema, L.; Aalderink, H.; Clifforde, I.T. Urban drainage impacts on receiving water quality. Water Sci. Technol. 1993, 27, 117-158.

2. Wilson, S.; Bray, R.; Cooper, P. Sustainable Drainage Systems: Hydraulic, Structural and Water Quality Advice; Construction Industry Research \& Information Association (CIRIA): London, UK, 2004.

3. Boogaard, F.; Lemmen, G.E. STOWA Stormwater Database: The Facts about the Quality of Stormwater Runoff, 2007-21 (in Dutch); De Stichting Toegepast Onderzoek Waterbeheer STOWA: Amersfoort, The Netherlands, 2007.

4. Van der Beesen, A.H.G.C. Fourth National Policy Document on Water Management (in Dutch); Ministry of Transport and Water: Den Haag, The Netherlands, 1998. 
5. Langeveld, J.G.; Liefting, H.J.; Boogaard, F.C. Uncertainties of stormwater characteristics and removal rates of stormwater treatment facilities: Implications for stormwater handling. Water Res. 2012, 46, 6868-6880.

6. Gobel, P.D.; Coldewey, W.G.C. Stormwater runoff concentration matrix for urban areas. J. Contam. Hydrol. 2007, 91, 26-42.

7. Particle Size Analysis-Laser Diffraction Methods-Part 1: General Principles, ISO 13320-1: 1999, IDT; AQSIQ of China, 16 April 2008.

8. Fuchs, S.; Brombach, H.; Wei, B.G. New Database on Urban Runoff Pollution. In Proceedings of the 5th International Conference Sustainable Techniques and Strategies in Urban Water Management, Lyon, France, 6-10 June 2004; pp. 145-152.

9. Bratieres, K.; Fletcher, T.D.; Deletic, A.; Zinger, Y. Nutrient and sediment removal by storm water biofilters: A large-scale design optimisation study. Water Res. 2008, 42, 3930-3940.

10. Duncan, H.P. Urban Stormwater Quality: A Statistical Overview; Cooperative Research Centre for Catchment Hydrology: Melbourne, Australia, 1999.

11. Stone, M.; Marsalek, J. Trace metal composition and speciation in street sediment. Water Air Soil Pollut. 1996, 87, 149-168.

12. Walker, D.; Passfield, F.; Phillips, S.; Botting, J.; Pitrans, H. Stormwater sediment properties and land use in Tea Tree Gully, South Australia. In Proceedings of the 17th AWWA Federal Convention, Melbourne, Australia, 1997.

13. Grant, S.B.; Rekhi, N.V.; Pise N.R. Reeves, R.L. A Review of the Contaminants and Toxicity Associated with Particles in Stormwater Runoff; California Department of Transportation: Sacramento, CA, USA, 2003. Available online: http://www.dot.ca.gov/hq/env/stormwater/pdf/ CTSW-RT-03-059.pdf (accessed on 17 March 2014).

14. Gromaire-Mertz, M.C.; Garnaud, S.G.; Chebbo, G.A. Characterisation of urban runoff pollution in Paris. Water Sci. Technol. 1999, 39, 1-8.

15. Daligault, A.; Meaudre, D.; Arnault, D.; Duc, V. Stormwater and lamella settlers: Efficiency and reality. Water Sci. Technol.1999, 39, 93-101.

16. Sansalone, J.J.; Buchberger, S.G. Characterization of solid and metal element distributions in urban highway stormwater. Water Sci. Technol. 1997, 36, 155-160.

17. Schueler, T.R. Performance of Two Wet Ponds in the Piedmont of North Carolina. In The Practice of Watershed Protection; Schueler, T.R., Holland, H.K.; Eds.; Center for Watershed Protection: Ellicott City, MD, USA, 2000.

18. Scholes, L.; Revitt, M.; Gasperi, J.; Donner, E. Priority Pollutant Behaviour in Stormwater Best Management Practices (BMPs). Available online: http://documents.er.dtu.dk/Projects/ScorePP/ ScorePP\%20D5.1\%20PP\%20behaviour\%20in\%20stormwater\%20BMPs,\%202008-02-15.pdf (accessed on 17 March 2014).

19. Taylor, G.D.; Fletcher, T.D.; Wong, T.H.F.; Breen, P.F.; Duncan, H.P. Nitrogen composition in urban runoff e implications for stormwater management. Water Res. 2005, 39, 1982-1989. 
20. Pitt, R. National Stormwater Quality Database (NSQD); Department of Civil and Environmental Engineering, University of Alabama: Tuscaloosa, AL, USA, 2004.

(C) 2014 by the authors; licensee MDPI, Basel, Switzerland. This article is an open access article distributed under the terms and conditions of the Creative Commons Attribution license (http://creativecommons.org/licenses/by/3.0/). 